\title{
Prawa Dzieci w XXI wieku - w 30. rocznicę ustanowienia Konwencji o Prawach Dziecka
}

30 lat temu, tj. 20 listopada 1989 r., Zgromadzenie Ogólne ONZ jednogłośnie uchwaliło Konwencję o Prawach Dziecka. Konwencja ta pozostaje do dziś najczęściej ratyfikowanym międzynarodowym traktatem dotyczącym praw człowieka! Ratyfikowały ją wszystkie państwa członkowskie Unii Europejskiej, a Konwencja stała się jednym z podstawowych punktów odniesienia w kształtowaniu polityki ochrony dziecka w Unii Europejskiej. Ponadto 20 listopada stał się Międzynarodowym Dniem Praw Dziecka.

W tym roku obchodzimy 30. rocznicę uchwalenia Konwencji o Prawach Dziecka. Z tej okazji 20 listopada 2019 r. Parlament Europejski („PE”) zorganizował w Brukseli uroczystość obchodów 30-lecia Konwencji o Prawach Dziecka.

Uroczystość zaszczyciło swoją obecnością wielu znamienitych gości. Wśród nich gościem honorowym była Królowa Belgów Matylda. Obecni byli również: Minister Spraw Zagranicznych Ghany - kraju, który jako pierwszy ratyfikował Konwencję o Prawach Dziecka - Shirley Ayorkor Botchwey; Zastępca Dyrektora Wykonawczego UNICEF Charlotte Petri Gornitzka; ambasadorowie wielu krajów; posłanki i posłowie Parlamentu Europejskiego; a także goście reprezentujący międzynarodowe środowiska uniwersyteckie oraz instytucje i organizacje zajmujące się dzieckiem i jego prawami. Sala obrad Parlamentu Europejskiego zgromadziła również gości najważniejszych, a mianowicie dzieci.

Obchody zainicjował Przewodniczący Parlamentu Europejskiego David Maria Sassoli, który otwierając uroczystość, rozpoczął od złożenia hołdu wszystkim tym, którzy wykazując się dalekowzrocznością i altruizmem, zapoczątkowali ogromnie trudną walkę o prawa dziecka. Wskazał przede wszystkim na Eglantine Jebb, która - poruszona losem dzieci po I wojnie światowej - w roku 1923 napisała i zgłosiła Lidze Narodów dokument, który stał się podstawą dla stworzenia pierwszego międzynarodowego dokumentu chroniącego prawa dzieci, tj. przyjętej przez Zgromadzenie Ogólne Ligi Narodów 
w 1924 r. Deklaracji Praw Dziecka, zwanej również Deklaracją Genewską. Właśnie tym dokumentem posłużył się polski pediatra i pedagog Janusz Korczak, kiedy podczas II wojny światowej wzywał do ochrony dzieci przed przemocą wojny. Jak podkreślił Przewodniczący PE D.M. Sassoli, to właśnie J. Korczak był pierwszą osobą, która domagała się uznania praw dziecka. J. Korczak został aresztowany przez gestapo i zginął wraz dziećmi w Treblince w roku 1942, lecz pamięć o nim jest ciągle żywa. Polska, ze względu na dążenia i walkę J. Korczaka o prawa dziecka, w 1979 r., tj. w setną rocznicę jego urodzin, zgłosiła ONZ propozycję, by powstał wiążący tekst dotyczący praw dziecka. Po 10 latach prac i trudnych negocjacji 20 listopada 1989 r. uchwalono i podpisano Konwencję o Prawach Dziecka. Stała się ona fundamentalnym dokumentem w walce o to, aby prawa każdego - również dzieci - były zagwarantowane i przestrzegane.

Po historycznym wprowadzeniu D.M. Sassoli odniósł się do największej światowej organizacji zajmującej się ochroną praw dziecka, tj. do UNICEF, dziękując za wszystko, co do tej pory zrobiła i robi nadal.

Przewodniczący D.M. Sassoli podkreślił ogromne znaczenie osiągnięć w kwestiach praw dziecka, z jakich możemy się dzisiaj cieszyć. Zwrócił jednak uwagę na konieczność uważnego spoglądania w przyszłość i podejmowania nowych wyzwań, które stawia przed nami świat w zakresie ochrony praw dziecka. Wskazał przy tym w szczególności na zagrożenia, jakie niesie ze sobą epoka cyfrowa. Ponadto Przewodniczący przywołał statystyki świadczące o dramatycznej sytuacji wielu dzieci, głównie wysokiej umieralność wśród dzieci (6 milionów dzieci poniżej 15. roku życia) oraz przetrzymywaniu ich $\mathrm{w}$ więzieniach (1,5 miliona dzieci).

W dalszej części swojego wystąpienia Przewodniczący D.M. Sassoli wskazał na działania, jakie instytucje Unii Europejskiej, a w szczególności Parlament Europejski, będą podejmowały w celu dalszej ochrony praw dziecka. Podkreślił on konieczność wykorzystania rozpoczynającej się nowej kadencji Parlamentu Europejskiego, w pracach którego ważne jest wyznaczenie jasnych celów dla ochrony praw dziecka na kolejne pięć lat. Przewodniczący podkreślił, że Parlament jest w trakcie prac nad uchwałą, która będzie inspirowana również wystąpieniami i dyskusjami, jakie podejmowane będą podczas rozpoczynających się uroczystości obchodów 30. rocznicy ustanowienia Konwencji o Prawach Dziecka. D.M. Sassoli podziękował też nowej Przewodniczącej Komisji Europejskiej Ursuli von der Leyen, która wskazała działania na rzecz ochrony praw dziecka jako jeden z priorytetów w pracy Komisji Europejskiej (KE). Jak zapewnił Sassoli, PE będzie podejmował systematyczne prace nad ochroną praw dziecka, zarówno w zakresie polityki wewnętrznej, jak i zewnętrznej. W tym celu powołano też koordynatorkę ds. ochrony praw dziecka - wiceprzewodniczącą Parlamentu Europejskiego Ewę Kopacz. Dodatkowo D.M. Sassoli podkreślił, że zgadzając się z założeniami UNICEF, należy mocno artykułować fakt, iż prawa dzieci są elementem zrównoważonego rozwoju, stąd należy podjąć wszelkie działania, aby zwalczać nadużycia oraz przemoc wobec dzieci, a także eliminować biedę. Należy ponadto ulepszyć dostęp do oświaty, zdrowej żywności oraz usług sanitarnych. 
Na koniec swego wystąpienia D.M. Sassoli podziękował ekspertom za podzielenie się swymi doświadczeniami, tworząc w ten sposób bardziej sprawiedliwą przyszłość dla dzieci. Podziękował też szczególnym gościom, tj. kilkorgu dzieciom z różnych stron świata, które znalazły się w gronie panelistów podczas uroczystości. Byli to: Bereket 16-letni Młody Lider z Dziecięcej Wioski SOS w Etiopii; Sioda - 14-letni członek Rady Dzieci (Children's Council); Maria - 14-letnia Młoda Liderka organizacji World Vision z Ugandy, Raina - 16-letni propagator Protokołu fakultatywnego nr 3 do Konwencji o Prawach Dziecka oraz aktywista Młodzieżowego Ruchu Klimatycznego; Akhrat 20-letni Młodzieżowy Ambasador organizacji Defence for Children. Wszyscy oni przemawiali podczas uroczystości w imieniu dzieci z całego świata.

Po uroczystym wprowadzeniu głos zabrała Królowa Belgów Matylda. Swoje wystąpienie rozpoczęła od wskazania, że jako honorowa przewodnicząca UNICEF w Belgii od wielu lat jeździ po całym świecie, propagując Cele Zrównoważonego Rozwoju ONZ. Podczas tych wyjazdów zawsze spotyka się z dziećmi, które zostały szczególnie dotknięte traumą wojny, dramatycznymi przeżyciami; z dziećmi, które doświadczają skrajnego ubóstwa; z dziećmi, które są chore czy niepełnosprawne. Królowa Matylda zwróciła uwagę na fakt, że dzieci i młodzież w obecnych czasach są w stanie wyrażać swoje obawy i sprawić, by ich głos został usłyszany, a także same zaproponować konkretne rozwiązania. W ten sposób przywitała na uroczystości wszystkie dzieci i młodzież, które odważnie podjęły się działania w imię obrony swoich praw. Królowa Matylda przywołała historyczny kontekst uchwalenia Konwencji o Prawach Dziecka, wskazując na szeroki konsensus, jaki panował w momencie jej ustanawiania oraz to, że została ratyfikowana przez niemal wszystkie państwa członkowskie ONZ. Poprawa sytuacji dzieci na świecie jest zatem celem, na którym zależy wszystkim. Podkreśliła wybrzmiewające w Konwencji szczególne prawa dzieci, jakimi są prawo do zdrowia i edukacji; prawo do ochrony przed skutkami ubóstwa i konfliktów oraz przed wszelkimi formami eksploatacji, wyzysku czy przemocy; prawo dzieci do wolności wyrażania opinii, dzięki któremu głos dziecka może zostać wreszcie słyszalny. Królowa Matylda wskazała na znaczące postępy, jakich dokonano w ciągu 30 lat od wdrożenia Konwencji, m.in.: zmniejszenie o połowę umieralności dzieci, zwiększenie dostępu do edukacji wczesnoszkolnej (także w państwach rozwijających się), spadek liczby małżeństw zawieranych przez dzieci, a także zmniejszenie liczby dzieci pracujących. Nadal jednak 12 milionów dziewcząt wychodzi przedwcześnie za mąż, a dziesiątki milionów dzieci pracują. Należy więc w dalszym ciągu podejmować ogromne wysiłki, aby zrealizować cele, które wyznaczyła sobie wspólnota międzynarodowa w 1989 r. Należy również podjąć działania wobec nowych problemów, jakimi są zmiany klimatyczne, zaostrzenie konfliktów zbrojnych, w których ofiarami są dzieci, a także konsekwencje wpływu na dzieci świata cyfrowego. Królowa podkreśliła ogromne znaczenie, jakie w realizacji praw dziecka ma dostęp do wyższej jakości edukacji czy dostęp dziewcząt do szkoły średniej w wielu rozwijających się krajach. Brak dobrej edukacji przyczynia się do ubóstwa, marginalizacji wielu środowisk, a także dyskryminacji płci. 
Wskazała również na konieczność zapewnienia zdrowia umysłowego wśród dzieci i młodzieży.

Na zakończenie Królowa Matylda podkreśliła, że przyjęcie Konwencji o Prawach Dziecka nie tylko wzbudziło wielkie nadzieje, ale także doprowadziło do konkretnych zmian. Od tego czasu całe pokolenie dzieci stało się dorosłymi, jednak tylko niektóre z nich mogły zrealizować swoje marzenia i nadzieje. Zatem aby zapewnić postęp, należy przywrócić pierwszy zapał, który towarzyszył wszelkim działaniom podczas przyjmowania Konwencji w roku 1989.

Następnie głos zabrał Ambasador Dobrej Woli UNICEF David Bisbal. Wspominając historyczną perspektywę ustanowienia Konwencji o Prawach Dziecka, w sposób szczególny zwrócił uwagę na obecną trudną sytuację wielu dzieci na świecie. W tym kontekście zwrócił się do europarlamentarzystów z postulatem, aby dzieciństwo znalazło się odtąd w centrum działań politycznych Parlamentu Europejskiego i zostało włączone $\mathrm{w}$ jego codzienną pracę.

Druga część konferencji została otwarta panelem pt. Wszystkie dzieci maja prawo do życia i rozwoju, który poświęcony był sytuacji praw dziecka w Unii Europejskiej. Panelowi temu przewodniczyła Pierwsza Wiceprzewodnicząca parlamentarnej Komisji Wolności Obywatelskich, Sprawiedliwości i Spraw Wewnętrznych (Komisja LIBE) Maite Pagazaurtundua.

Na wstępie M. Pagazaurtundua zwróciła uwagę na konieczność pochylenia się nad problematyką przestrzegania praw podstawowych wszystkich dzieci, również dzieci uchodźców, emigrantów czy bezpaństwowców. Zatem wszystkie dzieci, które przebywają na terenie Unii Europejskiej powinny móc korzystać z przysługujących im praw dziecka, powinny móc liczyć na ochronę. M. Pagazaurtundua wskazała ogromne znaczenie praw podstawowych dziecka w pracach Komisji LIBE nad wspólnym europejskim systemem azylowym oraz europejską polityką migracyjną. Z całą stanowczością podkreśliła, że zarówno Komisja LIBE, jak i cały Parlament Europejski nie spoczną, dopóki prawa dzieci nie będą w pełni respektowane. Zwróciła przy tym uwagę na naruszenia praw dziecka, które mają często miejsce m.in. podczas procedur rozwodowych rodziców, a także w przypadku spraw karnych, kiedy dzieci powoływane są do sądów w charakterze świadków lub gdy same są podejrzewane o popełnienie przestępstwa. Podkreśliła, że niezależnie od sytuacji, zgodnie z zagwarantowanymi przez Konwencję standardami, odzwierciedlonymi w Karcie Praw Podstawowych Unii Europejskiej, we wszelkich procedurach prawnych, prawa dziecka muszą być respektowane w sposób zgodny z orzecznictwem Trybunału Sprawiedliwości Unii Europejskiej.

Na koniec Przewodnicząca panelu, wskazując kolejnych panelistów, a wśród nich dzieci, podkreśliła ogromne znaczenie bezpośredniego ich udziału w debacie. Aktywność dzieci w uroczystości to ważny wymiar toczących się dyskursów na temat praw dziecka.

W panelu głos zabrali: Europejska Komisarz ds. Sprawiedliwości, Spraw Konsumenckich i Równości Płci Vera Jourova; Dyrektor Agencji Praw Podstawowych Unii Europejskiej Michael O’Flaherty; Przewodnicząca Eurochild oraz była Prezydent Malty Ma- 
rie-Louise Colerio Prece, a także troje młodych ludzi zaangażowanych w promocję praw dzieci, tj. wymienieni już wcześniej Akhrat, Raina i Sioda.

Komisarz V. Jourova wskazała obszary ochrony praw dziecka, którymi zajmuje się podległa jej Dyrekcja Generalna, tj. prace nad polepszeniem sytuacji dzieci migrantów w zakresie nie tylko wyżywienia i zapewnienia dachu nad głową, ale również perspektyw na przyszłość; prace nad poprawą sytuacji dzieci społeczności romskiej, która w niektórych krajach nadal jest postrzegana jako obywatele drugiej kategorii; promowanie wymiaru sprawiedliwości przyjaznego dzieciom, szczególnie dzieciom-ofiarom przemocy; działania w zakresie przerwania błędnego koła ubóstwa wśród dzieci; prace nad promowaniem hasła „zero tolerancji dla pracy dzieci”; prace w zakresie przyjęcia strategii ochrony dzieci z najsłabszych grup społecznych; działania na rzecz ochrony praw dzieci przed negatywnymi skutkami świata cyfrowego. W tym kontekście, w kwietniu 2019 r., odbyła się pierwsza platforma dialogu nt. praw dziecka.

Następnie głos zabrała Akhrad, 20-letnia uchodźczyni z Iraku, obecnie mieszkająca w Holandii. Zarysowała ona smutną historię swojego dzieciństwa, które - jak wskazała zostało jej zabrane. W swojej wypowiedzi podkreśliła fakt, że wiele dzieci imigrantów nie ma prawa do podejmowania decyzji w sprawach, które dotykają je bezpośrednio. Jednak nade wszystko poprosiła, aby pozwolić dzieciom być dziećmi.

Michael O’Flaherty - Dyrektor Agencji Praw Podstawowych Unii Europejskiej wspominając rok 1989, tj. rok ustanowienia Konwencji, podkreślił ogromne znaczenie dokumentu w walce o prawa człowieka, w którym dziecko jest definiowane nie tylko jako człowiek, którego należy chronić, ale jako człowiek, któremu należy dać pewną przestrzeń i szczególną ochronę. To właśnie Konwencja diametralnie zmieniła UNICEF, stając się jego najważniejszym dokumentem. Z kolei UNICEF stał się dzięki temu siłą napędową do włączenia praw dziecka w plany gospodarcze i stworzenia Celów Zrównoważonego Rozwoju. Konwencja, jak wskazał Michael O’Flaherty, zainicjowała wiele traktatów i przepisów. Autorzy Karty Praw Podstawowych Unii Europejskiej, w szczególności jej art. 24, w pełni zainspirowali się Konwencją o Prawach Dziecka.

Podkreślając konieczność dalszych działań na rzecz ochrony praw dziecka, M. O’Flaherty wskazał trzy obszary zasługujące na szczególną uwagę. Pierwszy obszar związany jest z migracją, która, gdy dotyczy dzieci, jest wysoce niepokojąca. Jako przykład wskazał niedawno odwiedzony przez siebie obóz Moria na wyspie Lesbos w Grecji. W obozie przebywa 1000 dzieci bez opiekunów, spośród których tylko 300 jest w bezpiecznym wydzielonym dla dzieci miejscu. Pozostałe natomiast znajdują się w jednym hangarze z resztą migrantatów. M. O’Flaherty wspomniał 12-letniego chłopca, którego spotkał w obozie i który zwrócił jego uwagę wytatuowanym na przedramieniu kałasznikowem. Kiedy zapytał go, dlaczego ma akurat taki tatuaż, chłopiec odpowiedział, że wytatuowany kałasznikow ma mu nieustannie przypominać, że musi w tym świecie walczyć o siebie. W kontekście tej historii podkreślił, że żadnemu dziecku na świecie nie powinno towarzyszyć tak dramatyczne myślenie. Drugi priorytet wskazany przez M. O’Flaherty’ego to konieczność integracji dzieci przybyłych do Europy 
w społeczeństwie europejskim i zdecydowane polepszenie standardów w tym zakresie. Trzeci wskazany priorytet to konieczność podjęcia działań w celu zapobiegania biedzie i ubóstwu wśród dzieci - 1/4, a więc 25 milionów dzieci w Unii Europejskiej żyje obecnie w ubogich domach i to pomimo faktu, że jest to najbogatszy rejon świata.

M O’Flaherty odniósł się również do poruszonej już wcześniej przez M. Pagazaurtundua kwestii miejsca dziecka $\mathrm{w}$ wymiarze sprawiedliwości i wspomnianego przez nią przykładu, kiedy dziecko występuje np. w charakterze świadka podczas sprawy rozwodowej swych rodziców. Podkreślił konieczność stworzenia odpowiednich, przyjaznych warunków i podejścia do dziecka w tym zakresie. Na zakończenie M. O’Flaherty wskazał, że Agencja, na czele której stoi, podejmuje wiele działań w celu zapobiegania trudnej sytuacji dziecka. Zwrócił się też do PE z postulatem podjęcia działań dla poprawy warunków życia dzieci w UE, apelując, aby w 30. rocznicę jej ustanowienia Konwencja o Prawach Dziecka wybrzmiewała w świecie głośniej.

Następnie głos zabrali kolejno 16-letnia Raina z Niemiec oraz 14-letni Sioda z Irlandii, dzieci, które świadome swych praw, podejmują działania dla ich ochrony i przestrzegania.

Raina jest aktywistką klimatyczną, która wraz z piętnaściorgiem innych dzieci złożyła skargę do Komitetu Praw Dziecka ONZ na mocy III Protokołu Fakultatywnego do Konwencji o Prawach Dziecka, zarzucając krajom, z których pochodzą (Argentyna, Brazylia, Francja, Niemcy, Turcja), brak skutecznego działania przeciwko zmianom klimatycznym. Podkreśliła ona ogromne zagrożenie, jakie niesie ze sobą kryzys klimatyczny dla całego świata. Wskazała na niebezpieczeństwo dalszego stosowania paliw kopalnych, podkreślając, w jak dużym stopniu zwiększy się migracja ludzi, którzy ze względu na ocieplenie klimatyczne będą musieli uciekać z własnych domów. Przypomniała, że tegoroczne lato $\mathrm{w}$ Niemczech było najgorętszym latem $\mathrm{w}$ historii. Zwróciła również uwagę na występujące ostatnio w wielu miejscach na Ziemi powodzie, które odbierają ludziom ich bliskich oraz ich domy, a wszystko to dzieje się tylko z powodu dominującego obecnie w świecie żałosnego - jak podkreśliła - modelu konsumpcyjnego. Raina zwróciła się do swego państwa, które mogąc mieć ogromny wpływ na środowisko naturalne, nadal inwestuje w paliwa kopalne, przysparzając tym samym wiele bólu i cierpienia społeczeństwom z innych części świata. Raina podkreśliła z całą stanowczością, że sposób, w jaki żyje się w Niemczech i w całej Europie, przyczynia się do zmian klimatycznych. Przypomniała, że uczy się dzieci, aby pomagać innym, słabszym. Dlaczego więc przywódcy państw, którzy kiedyś byli dziećmi i których również uczono tych samych zasad, teraz o nich zapominają. Raina domaga się podstawowych praw dla dzieci, tj. prawa do życia, do przyszłości i do bezpiecznego domu. Konwencja, jak podkreśliła, obiecała dzieciom ochronę, ale ta obietnica nie jest realizowana. Raina, jako przedstawicielka dzieci wychodzących co piątek na ulice wielu miast Europy i świata w walce o bezpieczny klimat, zwróciła się do rządów poszczególnych państw, podkreślając z całą stanowczością, że sprawa klimatu jest sprawą palącą, w której konieczne jest podjęcie natychmiastowych działań. 
Kolejnym przemawiającym był Sioda - członek Rady Dzieci stowarzyszenia Eurochild, tj. sieci organizacji, które podejmują działania dla zapewnienia godnego życia dzieciom. W Radzie zasiada jedenaścioro dzieci, a każde z nich reprezentuje inny kraj europejski i inną organizację działającą na szczeblu lokalnym. Jednym z działań podjętych przez Radę Dzieci Eurochild było przeprowadzenie ankiety wśród 20 tysięcy dzieci zatytułowanej „Czego chcą dzieci?”. Jej wyniki pokazują, że niezależnie od przestrzeni geograficznej, w której mieszkają dzieci, 52\% spośród nich obawia się o swoją przyszłość. Dzieci, a wśród nich w największym stopniu dzieci z Włoch, Rumunii i Polski, wyrażają obawy m.in. o swoją przyszłą sytuację na rynku pracy. Wielu dzieciom nie pozwala się uczyć i rozwijać w sposób zrównoważony. Ubóstwo, brak pracy rodziców, zdrowie psychiczne i fizyczne, to problemy, które nie pozwalają dzieciom żyć spokojnie i rozwijać się. Ważny problem wskazany przez dzieci, to nękanie w Internecie, którego wiele z nich pada ofiarami. Sioda podkreślił, że dorośli często nie traktują poważnie dzieci i podnoszonych przez nie kwestii, co niestety obniża motywację dzieci do działania, do aktywności. Przy czym - jak wskazał Sioda - należy pamiętać, że dzieci stanowią 25\% społeczeństwa i są stuprocentowymi obywatelami Europy, którzy mają swoje postulaty, pomysły na rozwiązanie wielu spraw i ich głos należy brać pod uwagę w takim samym stopniu jak głos osób dorosłych. W związku z tym, zwracając się do wszystkich zgromadzonych, europarlamentarzystów, przedstawicieli wielu organizacji i państw, podkreślając ich ogromną wiedzę i doświadczenie, poprosił, aby przyszłość dzieci była tworzona przy ich udziale. Jak podkreślił, instytucje europejskie muszą brać pod uwagę głos dzieci, które chcą zarówno bezpośrednio uczestniczyć we wszystkich działaniach podejmowanych na rzecz dzieci, jak również zatroszczyć się o przyszłość kolejnych pokoleń dzieci.

Jako ostatnia w tym panelu głos zabrała Marie-Louise Colerio Prece - Przewodnicząca Eurochild oraz była Prezydent Malty, która wskazała na wiele wyzwań dotyczących ochrony praw dziecka w kontekście zmieniającego się krajobrazu Europy, spośród których najważniejszymi są ubóstwo, migracja oraz niepełnosprawność. W kwestii ubóstwa podkreśliła, że dzieci z rodzin ubogich, których liczba w niektórych krajach Europy sięga ponad $40 \%$, mają o wiele gorszy start w życie dorosłe aniżeli dzieci z rodzin bogatszych. W kontekście migracyjnym wskazała dramatyczne dane za lata 2014-2017 mówiące o tym, że ponad 30 tys. dzieci uchodźców zaginęło w Europie. W tej sprawie w lutym 2019 r. na Malcie zorganizowano konferencję, podczas której wypracowano zalecenia, aby zająć się tą ogromną tragedią ludzką, która ma miejsce tu i teraz w Europie. M.-L. Colerio Prece wskazała na dramatyczną wręcz sytuację dziecka, które zmuszone jest wraz ze swoją rodziną do opuszczenia domu rodzinnego i do - często niebezpiecznej - podróży. Ponadto dzieci te po przybyciu do Europy często narażone są na kolejne niebezpieczeństwa, ponieważ wiele państw Europy nie jest przygotowanych i nie zapewnia im odpowiednich warunków, nie przestrzega podstawowych praw tych dzieci. W tym kontekście Eurochild oraz organizacja Save the Children nawołują do zmiany narracji wokół migracji, a w szczególności migracji dzieci. M.-L. Colerio Prece wskazała też na 
dzieci z niepełnosprawnościami i konieczność walki o ich prawa. Na koniec w imieniu Eurochild zaapelowała do Parlamentu Europejskiego i Komisji Europejskiej o wypracowanie do 2030 r. strategii, w której byłyby zawarte konkretne cele na rzecz rozwiązania zaprezentowanych postulatów.

W kolejnej części konferencji odbyła się runda pytań, które zadawali goście, przedstawiciele organizacji, reprezentanci środowisk akademickich, dzieci, podejmując i wskazując wiele problemów, a także pytając, kiedy i w jaki sposób palące sprawy wpływające na przestrzeganie praw dziecka będą rozwiązane. Poruszane zagadnienia dotyczyły: przemocy w Internecie, która dotyka dzieci; zaginionych dzieci; problemów zdrowia psychicznego dzieci, wskazując m.in. dzieci migrujące, które narażone są na potężny stres; homoseksualizmu wśród dzieci i pomocy dla nich w kontekście społeczno-kulturowym; prawa dzieci do edukacji; sytuacji dzieci przetrzymywanych w obozach dla uchodźców i planów, jakie wobec ich losu mają decydenci Europy. Wszyscy zadający pytania zostali zapewnieni o zdecydowanym uwzględnieniu w pracach PE i KE wysuwanych postulatów i wskazywanych problemów.

Drugi panel pt. Wszystkie dzieci maja prawo do marzeń dotyczył sytuacji praw dziecka poza Unią Europejską, a przewodniczyła mu Maria Arena - Przewodnicząca parlamentarnej Podkomisji Praw Człowieka. Panelistami byli: Minister Spraw Zagranicznych Ghany Shirley Ayorkor Botchwey; Zastępca Dyrektora Wykonawczego UNICEF Charlotte Petri Gornitzka; Wiceprzewodnicząca Komitetu Praw Dziecka ONZ Velina Todorova; ponadto głos zabrały dzieci: Maria - 14-letnia Młoda Liderka organizacji World Vision z Ugandy oraz 16-letni Bereket - Młody Lider z Dziecięcej Wioski SOS w Etiopii.

Maria Arena, otwierając tę część obrad, podkreśliła ogromne znaczenie otwartości i entuzjazmu, z jakim obecni na uroczystości wskazują obszary i przestrzenie ważne dla ochrony praw dziecka. Przypomniała wiele wskazywanych już wcześniej palących problemów, jak kwestia ochrony klimatu czy niebezpieczeństw, jakie niesie świat cyfrowy, ale też istotność ochrony dzieci przed związkami chemicznymi. M. Arena zwróciła szczególną uwagę na prawo dzieci do zdrowiej żywności, podając przykład procederu stosowanego przez wiodące firmy europejskie polegającego na produkowaniu pozbawionego naturalnego tłuszczu, sproszkowanego mleka, które jest w takiej formie wysyłane do krajów zachodniej Afryki.

Po wstępie głos zabrała Minister Spraw Zagranicznych Ghany Shirley Ayorkor Botchwey, która, przywołując historię powstania Konwencji o Prawach Dziecka, wskazała jednak, że Konwencja nie jest niestety obecna w politykach wszystkich państw sygnatariuszy, a jej zapisy jeszcze nie wszystkim są znane i odpowiednio rozumiane. Nadal bowiem prawa milionów dzieci są naruszane poprzez np. pracę nieletnich, małżeństwa nieletnich, brak dostępu do nauki czy do zdrowego żywienia, ale także rekrutowanie dzieci do wojska, gdzie zmuszane są do walki z dorosłymi, do udziału w konfliktach zbrojnych. S. Ayorkor Botchwey podkreśliła konieczność stworzenia wizji i zobowiązała przywódców, decydentów oraz rodziców do przestrzegania Konwencji o Prawach Dziecka. Podkreśliła przy tym ogromne znaczenie właściwych relacji między rodzicami a dziećmi, 
które dając dzieciom siłę i wzmacniając ich indywidualność, budują jednocześnie poczucie wartości i ważności dzieci. Na koniec zapewniła, że Ghana jako kraj, który pierwszy ratyfikował Konwencję o Prawach Dziecka, nadal jest mocno zaangażowana w ochronę tych praw.

W panelu wybrzmiał bardzo mocno głos 14-letniej Marii z Ugandy, młodej działaczki organizacji na rzecz ochrony praw dzieci World Vision. Maria stwierdziła, że jej rolą jest przede wszystkim głośne mówienie w imieniu tych wszystkich dzieci, które nie mogą lub nie potrafią mówić. Wskazała na konieczność odpowiedniej oświaty dla dzieci, gdyż tylko wówczas można im zapewnić dobre jutro - edukowane dziecko, to dobrze funkcjonujący w przyszłości, wykształcony dorosły. Podkreśliła konieczność walki z aktami przemocy i gwałtami na dzieciach. Jeśli tego nie uczynimy, dzieci bite i gwałcone w dorosłości dokonają takich samych aktów. Na koniec Maria zwróciła się do wszystkich decydentów, przywódców religijnych, nauczycieli oraz rodziców, aby podjęli wszelkie działania na rzecz walki z przemocą wobec dzieci, gdyż przemoc stosowana w dzieciństwie w dorosłości zawsze powraca.

Zastępca Dyrektora Wykonawczego UNICEF Ch. Petri Gornitzka zwróciła się z postulatem, aby dyskusje prowadzone w Parlamencie Europejskim, miejscu tak znaczącym dla demokracji europejskiej, zawsze poprzedzało następujące pytanie: „Jak to, co zrobimy, wpłynie na dzieci, na przyszłe pokolenia?”. Jako przedstawicielka UNICEF wskazała na wiele dokonań w zakresie ochrony i realizacji praw dziecka, jakie nastąpiły po uchwaleniu Konwencji, ale także unijnych przepisów. Zwróciła jednak uwagę na fakt, że nadal istnieje wiele problematycznych obszarów, w których konieczne jest wypracowanie rozwiązań. W ten sposób wezwała UE do podejmowania takich wyzwań, jak migracja, zmiany klimatyczne, cyfryzacja, choroby psychiczne wśród dzieci oraz polityka wobec dzieci w konfliktach zbrojnych.

Następnie głos zabrał 16-letni Bereket, który pochodzi z Etiopii, a obecnie mieszka w Ghanie. Bereket podzielił się swoimi doświadczeniami stanowiącymi świadectwo trudności, z jakimi zmaga się wiele etiopskich dzieci. Sam Bereket, jak podkreślał, miał ogromne szczęście, ponieważ w wieku 4 lat trafił do Dziecięcej Wioski SOS i tam przeżył 11 szczęśliwych lat. Obecnie, jako członek i przewodniczący w parlamencie wioski SOS, podejmuje wiele aktywności na rzecz ochrony praw dziecka. Jednym z największych osiągnięć Bareketa było uzyskanie stypendium i studia w prestiżowej szkole w Ghanie. Tam zdobywa wiedzę na temat służby publicznej, służby dla społeczeństwa. Na koniec podkreślił, że jego historia jest dowodem na to, że życie każdego dziecka może być dobre i szczęśliwe, kiedy przestrzega się jego praw, co w świecie powinno być normą, a nie wyjątkiem.

Ostatnią panelistką była Wiceprzewodnicząca Komitetu Praw Dziecka ONZ Velina Todorova. Zaprezentowała ona rolę Komitetu w globalnym monitorowaniu przestrzegania postanowień Konwencji o Prawach Dziecka. Jak wskazała, Komitet spotyka się z przedstawicielami państw, ale też trzykrotnie w ciągu roku spotyka się z dziećmi. Wysłuchuje również organizacji społeczeństwa obywatelskiego oraz rzeczników praw 
dziecka poszczególnych krajów. Wszystko to odbywa się w celu gromadzenia jak największej ilości informacji na temat sytuacji związanej z prawami dziecka w poszczególnych państwach. V. Todorova podkreśliła znaczenie Konwencji o Prawach Dziecka jako dokumentu, który wywołał prawno-kulturową rewolucję. Prawną dlatego, że dał dzieciom prawa na równi z prawami dorosłych, natomiast kulturową dlatego, że dokument ten wymagał zmian w normach społecznych, wartościach i postrzeganiu dzieci na świecie. V. Todorova podkreśliła też ważne miejsce dzieci w agendzie politycznej Unii Europejskiej wdrażanej nie tylko w Europie, ale także poza jej granicami. Wskazała jednak na wiele nowych problemów pozostających do rozwiązania, wymieniając - obok już przywołanych wcześniej, kolejne, tj. kary cielesne, przemoc wobec dzieci, ale też korupcję, zwiększoną aktywność ruchów ekstremistycznych. Na zakończenie podkreśliła, że 30-lecie Konwencji nadało jej zupełnie nową dynamikę i spowodowało odnowienie zaangażowania państw w ochronę praw dzieci.

Podsumowaniem drugiego panelu były refleksje i pytania zadawane przede wszystkim przez reprezentantów poszczególnych Dyrekcji Generalnych Komisji Europejskiej, ale również przez gości. Przedstawicielka Działu Praw Człowieka Dyrekcji Generalnej ds. Rozwoju i Współpracy Międzynarodowej (DG DEVCO), w odpowiedzi na wiele pojawiających się podczas debaty pytań związanych z ochroną praw dziecka i poziomem zaangażowania ze strony KE, wskazała prace, które Dyrekcja podjęła oraz które będzie kontynuowała w tym zakresie. Jednym z obszarów działań jest wyeliminowanie przemocy wobec kobiet i dziewcząt - to inicjatywa, która jest wdrażana w ośmiu państwach afrykańskich i pięciu Ameryki Łacińskiej, gdzie podejmowana jest współpraca z liderami, nauczycielami, samorządami i społeczeństwem obywatelskim. Ponadto wskazała, że DG DEVCO dąży do zapewnienia wszystkim dzieciom wysokiej jakości edukacji, do stworzenia przyjaznego dziecku wymiaru sprawiedliwości, realizuje pomoc humanitarną (64 miliony euro zostały już przeznaczone na ten cel). Kolejne osoby podejmujące głos przyznały, że wszystkie wypowiedzi dzieci podczas obrad wskazują na konieczność zdecydowanie większego zaangażowania się UE w prace na rzecz ochrony i przestrzegania praw dziecka na całym świecie.

W podsumowaniu przewodnicząca drugiego panelu zapewniła, że wszelkie podjęte podczas obrad problemy zostaną uwzględnione w pracach komisji parlamentarnych, a także w pracach KE i będą prowadzone przy wzajemnej współpracy.

Uroczystość obchodów 30. rocznicy ustanowienia Konwencji o Prawach Dziecka w Parlamencie Europejskim została podsumowana przez Wiceprzewodniczącą Parlamentu Europejskiego i Koordynatorkę ds. Praw Dziecka Ewę Kopacz, która odwołując się do historii, podkreśliła, że jako Polka z dumą może powołać się na przytaczanego już wcześniej Polaka - Janusza Korczaka, który walcząc o dziecięcą podmiotowość, zainicjował konieczność prawnego ustanowienia praw dzieci. 


\section{Zakończenie}

Uroczystość, jaka miała miejsce w Parlamencie Europejskim, była niebywałym wydarzeniem, podczas którego wszyscy starali się wymienić osiągnięcia, ale przede wszystkim potrzeby i oczekiwania, jakie stoją przed światem w zakresie ochrony praw dziecka.

Stanowiska swoje prezentowało wiele osób, wśród których znalazły się głowy państw, ambasadorowie, ministrowie, dyrektorzy największych światowych organizacji zajmujących się prawami dziecka, europarlamentarzyści. Jednak najważniejszy głos, który wybrzmiał podczas konferencji, to głos dzieci. To one, przedstawiając poszczególne palące problemy, którymi należy się zająć, prezentowały je w sposób szczery, serdeczny, otwarty, prosty, ale stanowczy. Przemawiając w imieniu swych rówieśników, mówiły o wszystkich ważnych sprawach głośno i bezkompromisowo, wzywając dorosłych do zajęcia się nimi.

Przeprowadzone debaty pozwoliły wskazać nowe konieczne kierunki działań, które w kontekście wyzwań współczesnego świata będą mogły doprowadzić do - miejmy nadzieję - pełnej realizacji ochrony praw dzieci, gdyż Prawa Dziecka to Prawa Człowieka! 